\title{
SUMBER DAYA INTERNAL PETERNAK SAPI PERAH DAN PENGARUHNYA TERHADAP DINAMIKA KELOMPOK DAN KONTEKS KERENTANAN
}

\author{
Internal Resources of Dairy Cattle Farming Business and Their Effect \\ on Group Dynamics and Vulnerability Context
}

\author{
Amam $^{1}$, M. Wildan Jadmiko', Pradiptya Ayu Harsita ${ }^{1}$, Nur Widodo', dan M. Setyo Poerwoko² \\ ${ }^{1}$ Department of Animal Husbandry, Faculty of Agriculture, University of Jember \\ ${ }^{2}$ Department of Agronomy, Faculty of Agriculture, University of Jember \\ Jl. Kalimantan No. 37 Kampus Tegalboto, Sumbersari, Jember, Jawa Timur 68121 \\ Email : amam.faperta@unej.ac.id
}

\begin{abstract}
This research aims to find out the influence of dairy farmer's internal resources on group dynamics and vulnerability context of dairy farming business. The research was conducted at the animal husbandry institution Kelompok Usaha Bersama (KUB) Tirtasari Kresna Gemilang in Pujon Subdistrict, Malang District, East Java Province on October - December 2018. The research variables consisted of financial resources $\left(X_{1}\right)$, technological resources $\left(X_{2}\right)$, physical resources $\left(X_{3}\right)$, group dynamics $\left(Z_{1}\right)$, and the context of vulnerability of dairy farming business $\left(Y_{1}\right)$. The respondents were all KUB member dairy farmers, namely 174 dairy farmers. Data were analyzed by the SEM (Structural Equation Model) method using SmartPLS 2.0. The results showed that the accessibility of dairy farmers to internal resources affected group dynamics by 33\%, while vulnerability context of dairy farming business was influenced by the dairy farmer's internal resources and group dynamics by 30.3\%. The conclusion of the research showed the role of resources could influence to group dynamics and vulnerability context of dairy farming business.
\end{abstract}

Keywords: Dairy Cattle, Farming Business, Group Dynamics, Internal Resources, Vulnerability Context.

\section{PENDAHULUAN}

Peraturan Menteri Pertanian (Permentan) Nomor 33 Tahun 2018 tentang Penyediaan dan Peredaran Susu sebagai bentuk kewajiban negara Indonesia selaku anggota Organisasi Perdagangan Dunia atau World Trade Organization (WTO). Hal tersebut berdampak pada upaya yang dilakukan oleh Kementerian Pertanian untuk mengembalikan aturan kemitraan peternak sapi perah dengan Industri Pengolahan Susu (IPS). Kemitraan peternak sapi perah dengan IPS di Indonesia masih sangat rendah, yaitu hanya 30 macam kemitraan, sedangkan 98 importir susu berasal dari luar negeri. Hasil dari kemitraan tersebut mampu meningkatkan nilai investasi sebesar 951,7 miliar rupiah yang diantaranya berupa sarana dan prasarana, serta gerakan minum susu di kalangan masyarakat.

Upaya pemerintah untuk mengurangi ketergantungan susu impor untuk memenuhi kebutuhan susu dalam negeri salah satunya ialah pemerintah harus lebih memperhatikan sektor peternakan sapi perah dalam negeri. Tasripin
(2018) mengatakan bahwa sebenarnya nilai ekonomi yang bisa diperoleh dari produk susu sapi perah lokal lebih menguntungkan jika dibandingkan dengan sapi potong. Hal tersebut dikarenakan sapi perah bisa panen setiap hari, sedangkan sapi potong masa panen sekitar empat bulan untuk mendapatkan keuntungan. Ironisnya, selama ini susu segar lokal dibiarkan bersaing sendiri dengan susu segar impor. Akibatnya, susu segar dari peternak sapi lokal kalah bersaing dan sulit berkembang.

Dampak tersebut secara langsung mempengaruhi keuntungan dan kesejahteraan peternak. Salah satu upaya yang dilakukan untuk mengatasi kondisi tersebut yaitu dengan memanfaatkan segala potensi sumber daya peternak sapi perah. Sumber daya tersebut diantaranya yaitu sumber daya internal yang terdiri dari sumber daya finansial, sumber daya teknologi, dan sumber daya fisik (Syukur et al., 2014). Sumber daya tersebut menurut Syukur et al. (2014) dapat mempengaruhi dinamika kelompok peternak dan konteks kerentanan dalam usaha ternak sapi potong model gaduhan. 
Sumber daya finansial peternak sapi perah ialah sumber daya yang dapat diakses peternak sapi perah yang erat kaitannya dengan aset keuangan (modal). Jenis sumber daya finansial peternak sapi perah meliputi: pendapatan utama, pendapatan dari usaha ternak sapi perah, pendapatan dari usaha non-peternakan, pendapatan dari usaha ternak lain, pendapatan total untuk kebutuhan hidup sehari-hari, jumlah tabungan, jumlah hutang, jumlah pelunasan hutang, kepemilikan sapi pedet, kepemilikan sapi dara, kepemilikan sapi bunting, kepemilikan sapi produksi, kepemilikan sapi kering, dan jumlah populasi sapi yang dipelihara.

Sumber daya teknologi peternak sapi perah ialah sumber daya yang dapat diakses peternak sapi perah yang berkaitan dengan adopsi, inovasi, dan implikasi teknologi. Jenis sumber daya teknologi meliputi: pemilihan indukan, pakan, kesehatan ternak, perkandangan, pemasaran susu, dan teknologi peningkatan produksi susu.

Sumber daya fisik peternak sapi perah ialah sumber daya yang dapat diakses peternak yang erat kaitannya dengan prasarana dan sarana produksi untuk mendukung usaha ternaknya. Jenis sumber daya fisik meliputi: rumah tempat tinggal, kandang ternak, sarana transportasi, sarana komunikasi, sarana informasi, listrik rumah tangga, penguasaan lahan, penggunaan lahan, ketersediaan sumber air, dan ketersediaan sumber pakan.

Aspek sumber daya finansial, sumber daya teknologi, dan sumber daya fisik peternak berpengaruh secara positif signifikan terhadap dinamika kelompok sebagai bentuk kelembagaan di tingkat peternak (Syukur et al., 2014). Hal tersebut menunjukkan bahwa sumber daya finansial yang dapat diakses peternak mendukung dinamika kelompok peternak. Dinamika kelompok peternak adalah perubahan kelompok untuk terus berupaya menyesuaikan diri dengan keadaan. Aspek dinamika kelompok meliputi: sarana kelompok, capaian tujuan kelompok, fungsi dan tugas kelompok, struktur kelompok, kerukunan anggota kelompok, dan bentuk kelembagaan.

Konteks kerentanan usaha ternak adalah sebuah kondisi yang cenderung berisiko atau akan berisiko (berdasarkan pengalaman) sehingga berdampak pada tingkat kerugian peternak. Konteks kerentanan di lokasi penelitian terdiri dari musim, keamanan, penyakit ternak, fluktuasi harga susu, kebijakan pemerintah, kebijakan kelompok, dan moralitas peternak. Konteks kerentanan tersebut mempengaruhi pengembangan usaha ternak sapi perah di KUB Tirtasari Kresna Gemilang. Pentingnya kajian konteks kerentanan karena pengembangan usaha ternak berpengaruh negatif terhadap risiko bisnis usaha ternak (Amam dan Soetriono, 2019). Penelitian bertujuan untuk: 1) mengkaji pengaruh sumber daya peternak sapi perah terhadap dinamika kelompok; dan 2) mengkaji pengaruh sumber daya peternak sapi perah terhadap konteks kerentanan.

\section{MATERI DAN METODE}

\section{Waktu dan Lokasi Penelitian}

Pengambilan data penelitian di lapang dilaksanakan bulan Oktober hingga Desember 2018. Lokasi penelitian yaitu Kecamatan Pujon Kabupaten Malang. Pemilihan lokasi ditentukan secara purposive dengan pertimbangan bahwa Kecamatan Pujon Kabupaten Malang mempunyai populasi ternak sapi perah yang mencapai 20.670 ekor (BPS, 2017).

\section{Variabel Penelitian}

Penelitian ini terdiri dari 5 variabel utama dan 43 indikator. Variabel utama (Tabel 1) yaitu: a) sumber daya finansial, b) sumber daya teknologi, c) sumber daya fisik, d) dinamika kelompok, dan e) konteks kerentanan.

Tabel 1. Variabel dan Indikator Penelitian

\begin{tabular}{lc}
\hline A. Sumber Daya Finansial $\left(\mathbf{X}_{\mathbf{1}}\right)$ & Notasi \\
\hline Pendapatan utama & $\mathrm{X}_{1.1}$ \\
Pendapatan dari usaha ternak sapi perah & $\mathrm{X}_{1.2}$ \\
Pendapatan dari usaha selain peternakan & $\mathrm{X}_{1.3}$ \\
Pendapatan dari usaha ternak lain & $\mathrm{X}_{1.4}$ \\
Pendapatan total untuk kebutuhan hidup sehari-hari & $\mathrm{X}_{1.5}$ \\
Jumlah tabungan & $\mathrm{X}_{1.6}$ \\
Jumlah hutang & $\mathrm{X}_{1.7}$ \\
Pelunasan hutang & $\mathrm{X}_{1.8}$ \\
Kepemilikan sapi pedet & $\mathrm{X}_{1.9}$ \\
Kepemilikan sapi dara & $\mathrm{X}_{1.10}$ \\
Kepemilikan sapi bunting & $\mathrm{X}_{1.11}$ \\
Kepemilikan sapi produksi & $\mathrm{X}_{1.12}$
\end{tabular}




\begin{tabular}{|c|c|}
\hline A. Sumber Daya Finansial $\left(\mathbf{X}_{1}\right)$ & Notasi \\
\hline Kepemilikan sapi periodekering & $\mathrm{X}_{1.13}$ \\
\hline Jumlah populasi sapi yang dipelihara & $\mathrm{X}_{1.14}$ \\
\hline B. Sumber Daya Teknologi $\left(\mathrm{X}_{2}\right)$ & Notasi \\
\hline Pemilihan sapi indukan (bibit) & $\mathrm{X}_{2.1}$ \\
\hline Teknologi pakan & $\mathrm{X}_{2.2}$ \\
\hline Kesehatan ternak & $\mathrm{X}_{2.3}$ \\
\hline Perkandangan & $\mathrm{X}_{2.4}$ \\
\hline Pemasaran susu & $\mathrm{X}_{2.5}$ \\
\hline Teknologi peningkatan produksi susu & $\mathrm{X}_{2.6}$ \\
\hline C. Sumber Daya Fisik $\left(\mathbf{X}_{3}\right)$ & Notasi \\
\hline Rumah tempat tinggal & $\mathrm{X}_{3.1}$ \\
\hline Kandang sapi & $\mathrm{X}_{3.2}$ \\
\hline Sarana transportasi & $\mathrm{X}_{3.3}$ \\
\hline Sarana komunikasi & $\mathrm{X}_{3.4}$ \\
\hline Sarana informasi & $\mathrm{X}_{3.5}$ \\
\hline Penggunaan listrik & $\mathrm{X}_{3.6}$ \\
\hline Penguasaan lahan & $\mathrm{X}_{3.7}$ \\
\hline Penggunaan lahan & $\mathrm{X}_{3.8}$ \\
\hline Ketersediaan sumber air & $\mathrm{X}_{3.9}$ \\
\hline Ketersediaan sumber pakan & $\mathrm{X}_{3.10}$ \\
\hline D. Dinamika Kelompok $\left(\mathrm{Z}_{1}\right)$ & Notasi \\
\hline Sarana kelompok ternak & $\mathrm{Z}_{1.1}$ \\
\hline Capaian tujuan kelompok & $\mathrm{Z}_{1.2}$ \\
\hline Fungsi dan tugas kelompok & $\mathrm{Z}_{1.3}$ \\
\hline Struktur kelompok & $\mathrm{Z}_{1.4}$ \\
\hline Kerukunan kelompok & $\mathrm{Z}_{1.5}$ \\
\hline Bentuk kelembagaan & $\mathrm{Z}_{1.6}$ \\
\hline E. Konteks Kerentanan $\left(\mathrm{Y}_{1}\right)$ & Notasi \\
\hline Musim & $\mathrm{Y}_{1.1}$ \\
\hline Keamanan & $\mathrm{Y}_{1.2}$ \\
\hline Penyakit ternak & $\mathrm{Y}_{1.3}$ \\
\hline Fluktuasi harga susu & $\mathrm{Y}_{1.4}$ \\
\hline Kebijakan pemerintah & $\mathrm{Y}_{1.5}$ \\
\hline Kebijakan kelompok & $\mathrm{Y}_{1.6}$ \\
\hline Moralitas peternak & $\mathrm{Y}_{1.7}$ \\
\hline
\end{tabular}

\section{Populasi Penelitian}

Responden adalah peternak sapi perah di Kecamatan Pujon Kabupaten Malang yang tergabung di dalam kelembagaan KUB (Kelompok Usaha Bersama) Tirtasari Kresna Gemilang. KUB merupakan suatu organisasi yang berdiri tahun 2017 yang dibentuk peternak sapi perah di Desa Ngabab untuk menunjang dan melindungi keberlangsungan usaha ternak sapi perah di era pasar bebas. KUB beranggotakan 174 peternak sapi perah, sehingga di dalam penelitian ini semua anggota KUB dijadikan responden (total sampling) untuk mendapatkan data primer.

\section{Pengumpulan Data}

Data diperoleh secara langsung dari responden dengan menggunakan metode pengisian kuisioner (angket) berskala likert 1 sampai dengan 5, metode wawancara, dan observasi untuk pengamatan langsung. Jenis data yang digunakan dalam penelitian ialah data primer yang bersumber langsung dari peternak dan data sekunder yang bersumber dari KUB, BPS, dan Dinas Peternakan.

\section{Analisis Data}

Data dianalisis dengan metode SEM (Structural Equation Model) dengan menggunakan alat aplikasi SmartPLS 2.0. Hasil analisis tersebut digunakan untuk menjawab hipotesis. Penggunaan aplikasi SmartPLS 2.0 bertujuan untuk menemukan teori baru atau memperkuat teori yang lemah (Wiyono, 2011). Hipotesis penelitian yaitu: sumber daya internal peternak sapi perah mempengaruhi dinamika kelompok dan konteks kerentanan usaha ternak sapi perah. 


\section{HASIL DAN PEMBAHASAN}

\begin{abstract}
Kelompok Usaha Bersama (KUB) Tirtasari Kresna Gemilang merupakan kelembagaan peternak sapi perah. KUB beranggotakan 174 orang yang sebagian besar menjalankan usaha ternaknya secara turun menurun, sehingga kondisi sosial ekonomi dan kelembagaan yang terbentuk merupakan sebuah warisan yang berupa tradisi untuk memelihara sapi perah. Mukson et al. (2012) menyebutkan bahwa kondisi lingkungan, sosial, ekonomi, kelembagaan, dan lingkungan usaha penting untuk diperhatikan mengingat dapat meningkatkan produktivitas usaha dan pendapatan peternak.
\end{abstract}

\section{Uji Indikator}

Sumber daya finansial peternak sapi perah ialah sumber daya yang dapat diakses peternak sapi perah yang erat kaitannya dengan aset keuangan (modal). Peternak di Kelompok Usaha Bersama (KUB) Tirtasari Kresna Gemilang mempunyai kekuatan sumber daya finansial, sehingga berdampak pada keberlanjutan usaha ternak sapi perah yang. Sumber daya teknologi peternak sapi perah ialah sumber daya yang dapat diakses peternak sapi perah yang berkaitan dengan adopsi, inovasi, dan implikasi teknologi. Peternak di KUB Tirtasari Kresna Gemilang mempunyai kekuatan sumber daya teknologi berupa manajemen seleksi bibit, manajemen perkandangan, dan upaya untuk meningkatkan produksi susu. Sumber daya fisik peternak sapi perah ialah sumber daya yang dapat diakses peternak yang erat kaitannya dengan prasarana dan sarana produksi untuk mendukung usaha ternaknya. Peternak di KUB Tirtasari Kresna Gemilang mempunyai kekuatan sumber daya fisik berupa rumah tempat tinggal, penguasaan lahan, penggunaan lahan, dan akses terhadap sumber air. Indikator pendukung variabel utama dalam penelitian diuji dengan menggunakan Smart PSL 2.0. Indikator yang memenuhi syarat dan dinyatakan valid yaitu indikator yang nilai outer loading-nya $>0.500$. Hasil uji indikator tersebut disajikan pada Tabel 2.

Tabel 2. Nilai Outer Loading

\begin{tabular}{|c|c|c|c|c|c|c|}
\hline & $\mathbf{X}_{1}$ & $X_{2}$ & $\mathbf{X}_{3}$ & $Z_{1}$ & $Y_{1}$ & Result \\
\hline $\mathrm{X}_{1.1}$ & 0.765 & & & & & valid \\
\hline $\mathbf{X}_{1.2}$ & 0.690 & & & & & valid \\
\hline $\mathbf{X}_{1.5}$ & 0.736 & & & & & valid \\
\hline $\mathbf{X}_{1.9}$ & 0.534 & & & & & valid \\
\hline $\mathbf{X}_{1.11}$ & 0.692 & & & & & valid \\
\hline$X_{1.12}$ & 0.634 & & & & & valid \\
\hline $\mathbf{X}_{1.13}$ & 0.534 & & & & & valid \\
\hline $\mathbf{X}_{1.14}$ & 0.879 & & & & & valid \\
\hline$X_{2.1}$ & & 0.759 & & & & valid \\
\hline $\mathbf{X}_{2.4}$ & & 0.700 & & & & valid \\
\hline $\mathbf{X}_{2.6}$ & & 0.733 & & & & valid \\
\hline $\mathbf{X}_{3.1}$ & & & 0.686 & & & valid \\
\hline $\mathbf{X}_{3.7}$ & & & 0.643 & & & valid \\
\hline $\mathbf{X}_{3.8}$ & & & 0.809 & & & valid \\
\hline $\mathrm{X}_{3.9}$ & & & 0.676 & & & valid \\
\hline$Z_{1.1}$ & & & & 0.593 & & valid \\
\hline $\mathrm{Z}_{1.2}$ & & & & 0.733 & & valid \\
\hline$Z_{1.3}$ & & & & 0.870 & & valid \\
\hline $\mathbf{Z}_{1.4}$ & & & & 0.786 & & valid \\
\hline $\mathbf{Y}_{1.4}$ & & & & & 0.800 & valid \\
\hline$Y_{1.5}$ & & & & & 0.845 & valid \\
\hline $\mathbf{Y}_{1.6}$ & & & & & 0.852 & valid \\
\hline $\mathbf{Y}_{1.7}$ & & & & & 0.813 & valid \\
\hline
\end{tabular}

Sumber: Data diolah (2018)

Hasil uji indikator menunjukkan bahwa akses peternak sapi perah di KUB Tirtasari Kresna Gemilang Kecamatan Pujon Kabupaten Malang terhadap sumber daya finansial terdiri dari: pendapatan utama $\left(\mathrm{X}_{1.1}\right)$, pendapatan dari usaha ternak sapi perah $\left(\mathrm{X}_{1.2}\right)$, pendapatan total untuk kebutuhan hidup sehari-hari $\left(\mathrm{X}_{1.5}\right)$, kepemilikan sapi pedet $\left(\mathrm{X}_{1.9}\right)$, kepemilikan sapi buting $\left(\mathrm{X}_{1.11}\right)$, kepemilikan sapi produksi $\left(\mathrm{X}_{1.12}\right)$, 
kepemilikan sapi periode kering $\left(\mathrm{X}_{1.13}\right)$, dan jumlah populasi sapi yang dipelihara $\left(\mathrm{X}_{1.14}\right)$.

Hasil uji indikator menunjukkan bahwa akses peternak sapi perah di KUB Tirtasari Kresna Gemilang Kecamatan Pujon Kabupaten Malang terhadap sumber daya teknologi terdiri dari: pemilihan sapi indukan sebagai bibit $\left(\mathrm{X}_{2.1}\right)$, perkandangan $\left(\mathrm{X}_{2.4}\right)$, dan teknologi peningkatan produksi susu $\left(\mathrm{X}_{2.6 .}\right)$

Hasil uji indikator menunjukkan bahwa akses peternak sapi perah di KUB Tirtasari Kresna Gemilang Kecamatan Pujon Kabupaten Malang terhadap sumber daya fisik terdiri dari: rumah tempat tinggal $\left(\mathrm{X}_{3.1}\right)$, penguasaan lahan $\left(\mathrm{X}_{3.7}\right)$, penggunaan lahan $\left(\mathrm{X}_{3.8}\right)$, dan ketersediaan sumber air $\left(\mathrm{X}_{3.9}\right)$.

Hasil uji indikator menunjukkan bahwa dinamika kelompok peternak sapi perah di KUB Tirtasari Kresna Gemilang Kecamatan Pujon Kabupaten Malang yang dipengaruhi oleh akses peternak terhadap sumber daya terdiri dari: sarana kelompok ternak $\left(Z_{1.1}\right)$, capaian tujuan kelompok $\left(\mathrm{Z}_{1.2}\right)$, fungsi dan tugas kelompok $\left(\mathrm{Z}_{1.3}\right)$, dan struktur kelompok ternak $\left(\mathrm{Z}_{1.4}\right)$.

Hasil uji indikator menunjukkan bahwa konteks kerentanan peternak sapi perah di KUB Tirtasari Kresna Gemilang Kecamatan Pujon Kabupaten Malang yang dipengaruh oleh akses peternak terhadap sumber daya terdiri dari: fluktuasi harga susu $\left(\mathrm{Y}_{1.4}\right)$, kebijakan pemerintah $\left(\mathrm{Y}_{1.5}\right)$, kebijakan kelompok $\left(\mathrm{Y}_{1.6}\right)$, dan moralitas peternak $\left(\mathrm{Y}_{1.7}\right)$.

\section{Uji Struktural}

Teknik analisis SEM dengan menggunakan SmartPLS 2.0 menghasilkan kriteria uji struktural berupa CR (Composite Reliability), nilai $\mathrm{R}^{2}$ ( $\mathrm{R}$ Square), dan nilai CA (Cronbach's Alpha). Hasil uji kriteria disajikan pada Tabel 3 dan Gambar 1.

Tabel 3. Uji Struktural

\begin{tabular}{l|ccc}
\hline & $\mathbf{C R}$ & $\mathbf{R}^{2}$ & $\mathbf{C A}$ \\
\hline $\mathbf{X}_{\mathbf{1}}$ & 0.877 & & 0.859 \\
$\mathbf{X}_{\mathbf{2}}$ & 0.774 & & 0.571 \\
$\mathbf{X}_{\mathbf{3}}$ & 0.798 & & 0.673 \\
$\mathbf{Z}_{\mathbf{1}}$ & 0.837 & 0.329 & 0.743 \\
$\mathbf{Y}_{\mathbf{1}}$ & 0.897 & 0.303 & 0.851 \\
\hline
\end{tabular}

Sumber: Data diolah (2018)



Gambar 1. Hasil Logaritma PLS

Uji struktural pada uji hipotesis atau uji pengaruh dilakukan setelah melakukan uji indikator yang terdiri dari nilai koefisien determinasi $\left(\mathrm{R}^{2}\right)$, nilai t-statistik, dan nilai 
koefisien parameter. Hasil uji tersebut disajikan pada Tabel 4.

Tabel 4. Uji Model

\begin{tabular}{|c|c|}
\hline Pengujian & Hasil Uji \\
\hline \multicolumn{2}{|l|}{ Koefisien Determinasi $\mathrm{R}^{2}$} \\
\hline Dinamika Kelompok & 0.330 \\
\hline Konteks Kerentanan & 0.303 \\
\hline \multicolumn{2}{|l|}{ T-statistik } \\
\hline $\mathrm{X}_{1} \rightarrow \mathrm{Z}_{1}$ & 0.017 \\
\hline $\mathrm{X}_{2} \rightarrow \mathrm{Z}_{1}$ & 5.858 \\
\hline $\mathrm{X}_{3} \rightarrow \mathrm{Z}_{1}$ & 2.652 \\
\hline $\mathrm{X}_{1} \rightarrow \mathrm{Y}_{1}$ & 2.321 \\
\hline $\mathrm{X}_{2} \rightarrow \mathrm{Y}_{1}$ & 0.127 \\
\hline $\mathrm{X}_{3} \rightarrow \mathrm{Y}_{1}$ & 0.901 \\
\hline $\mathrm{Z}_{1} \rightarrow \mathrm{Y}_{1}$ & 2.790 \\
\hline \multicolumn{2}{|l|}{ Koefisien Parameter } \\
\hline$\overline{X_{1} \rightarrow Z_{1}}$ & 0.002 \\
\hline $\mathrm{X}_{2} \rightarrow \mathrm{Z}_{1}$ & 0.463 \\
\hline $\mathrm{X}_{3} \rightarrow \mathrm{Z}_{1}$ & -0.299 \\
\hline $\mathrm{X}_{1} \rightarrow \mathrm{Y}_{1}$ & 0.306 \\
\hline $\mathrm{X}_{2} \rightarrow \mathrm{Y}_{1}$ & -0.163 \\
\hline $\mathrm{X}_{3} \rightarrow \mathrm{Y}_{1}$ & 0.219 \\
\hline $\mathrm{Z}_{1} \rightarrow \mathrm{Y}_{1}$ & -0.321 \\
\hline
\end{tabular}

Sumber: Data diolah (2018)

Pengaruh Sumber Daya Internal Peternak Sapi Perah terhadap Dinamika Kelompok

Sumber daya internal peternak di Kelompok Usaha Bersama (KUB) Tirtasari Kresna Gemilang terdiri dari sumber daya finansial, sumber daya teknologi, dan sumber daya fisik. Dinamika kelompok dipengaruhi oleh sumber daya internal peternak sapi perah sebesar $33 \%$, sedangkan sisanya sebesar $67 \%$ dipengaruhi oleh faktor lain yang tidak terdapat di dalam model. Sumber daya internal tersebut yaitu sumber daya finansial, sumber daya teknologi, dan sumber daya fisik. Amam dan Harsita (2019) menyatakan bahwa performa kelembagaan mempengaruhi SDM (Sumber Daya Manusia) peternak sapi perah secara positif.

Sumber daya finansial memberikan pengaruh yang signifikan terhadap dinamika kelompok sebesar 2.321. Pengaruh tersebut menunjukkan hasil positif sebesar $30.6 \%$. Artinya, semakin besar akses peternak terhadap sumber daya finansial maka semakin besar pengaruh peternak sapi perah terhadap dinamika kelompok. Kondisi sosial di lokasi penelitian menunjukkan bahwa pengaruh sumber daya finansial berdampak pada dinamika kelompok peternak sapi perah. Skala usaha sangat berpengaruh terhadap produktivitas ternak (Riszqina et al., 2014) oleh sebab itu Asmara et al. (2017) menyatakan bahwa produktivitas dan profitabilitas usaha ternak skala besar lebih tinggi jika dibandingkan dengan usaha ternak skala kecil.

Sumber daya teknologi memberikan pengaruh tetapi tidak signifikan terhadap dinamika kelompok sebesar 0.127. Pengaruh tersebut menunjukkan hasil negatif sebesar $16.3 \%$. Artinya, semakin besar akses peternak terhadap sumber daya teknologi maka semakin kecil pengaruh peternak sapi perah terhadap dinamika kelompok. Sumber daya teknologi yang terdiri dari metode pemilihan bibit, manajemen perkandangan, dan teknik untuk meningkatkan produksi susu sudah tidak lagi dianggap sebagai hal baru bagi peternak sapi perah karena rata-rata peternak mempunyai pengalaman lebih dari 20 tahun dan merupakan usaha yang secara turun menurun diwariskan oleh orang tuanya. Hermanto (2018) menjelaskan bahwa tantangan pertanian di masa depan lebih kompleks, dibutuhkan sinergi antara teknologi dan inovasi, penyempurnaan kebijakan, serta penguatan kelembagaan.

Sumber daya fisik memberikan pengaruh tetapi tidak signifikan terhadap dinamika kelompok sebesar 0.901. Pengaruh tersebut menunjukkan hasil positif sebesar $21.9 \%$. Artinya, semakin besar akses peternak terhadap sumber daya fisik maka semakin besar pengaruh peternak sapi perah terhadap dinamika kelompok. Pengelolaan sumber daya fisik seperti melakukan 
sistem integrasi tanaman dengan ternak dapat meningkatkan penerimaan dan pendapatan peternak (Tawaf et al., 2016).

\section{Pengaruh Sumber Daya Internal Peternak Sapi Perah terhadap Konteks Kerentanan}

Sumber daya internal peternak di Kelompok Usaha Bersama (KUB) Tirtasari Kresna Gemilang terdiri dari sumber daya finansial, sumber daya teknologi, dan sumber daya fisik. Konteks kerentanan dipengaruhi oleh sumber daya internal peternak sapi perah dan dinamika kelompok sebesar $30.3 \%$, sedangkan sisanya sebesar $69,7 \%$ dipengaruhi oleh faktor lain yang tidak terdapat di dalam model. Sumber daya tersebut yaitu sumber daya finansial, sumber daya teknologi, dan sumber daya fisik. Amam dan Harsita (2019) menyatakan bahwa konteks kerentanan sebagai aspek risiko bisnis mempengaruhi SDM (Sumber Daya Manusia) peternak sapi perah secara positif. Dinamika kelompok tani yang baik terlihat dari kuatnya faktor-faktor yang dapat menggerakkan perilaku anggota untuk dapat mencapai tujuan dengan efektif dan efisien secara bersama-sama (Suswandi dan Sutarno, 2017).

Sumber daya finansial memberikan pengaruh tetapi tidak signifikan terhadap konteks kerentanan sebesar 0.017. Pengaruh tersebut menunjukkan hasil positif sebesar 2\%. Artinya, semakin besar akses peternak terhadap sumber daya finansial maka semakin besar kemampuan peternak sapi perah dalam menghadapi konteks kerentanan. Sumekar et al. (2013) menjelaskan bahwa jumlah populasi, manajemen pakan, dan penguasaan teknologi peternak kurang optimal, sehingga belum bisa melakukan efisiensi biaya produksi seperti pakan dan penggunaan obatobatan (Pakage et al., 2015) serta risiko pembibitan, sanitasi, kesehatan ternak, dan manajemen pemberian pakan (Septiani et al., 2017).

Sumber daya teknologi memberikan pengaruh signifikan terhadap konteks kerentanan sebesar 5.858. Pengaruh tersebut menunjukkan hasil positif sebesar $46.3 \%$. Artinya, semakin besar akses peternak terhadap sumber daya teknologi maka semakin besar kemampuan peternak sapi perah dalam menghadapi konteks kerentanan. Contoh akses peternak terhadap sumber daya teknologi adalah pemilihan bibit sapi perah, sehingga melakukan pembibitan sendiri merupakan salah satu langkah awal untuk memulai langkah investasi (Perilla et al., 2009).

Sumber daya fisik memberikan pengaruh signifikan terhadap konteks kerentanan sebesar 2.652. Pengaruh tersebut menunjukkan hasil negatif sebesar $-29.9 \%$. Artinya, semakin besar akses peternak terhadap sumber daya fisik maka semakin kecil kemampuan peternak dalam mengahadapi konteks kerentanan. Hal tersebut terjadi karena di lokasi penelitian penguasaan lahan dan penggunaan lahan sudah mulai beralih fungsi menjadi tempat wisata, sehingga berkurangnya lahan untuk hijauan pakan dan kandang sapi, padahal menurut Tawaf et al. (2016) konsep integrasi tanaman dengan ternak dapat meningkatkan pendapatan peternak.

\section{Pengaruh Dinamika Kelompok terhadap Konteks Kerentanan \\ Dinamika kelompok memberikan} pengaruh signifikan terhadap konteks kerentanan sebesar 2.790. Pengaruh tersebut memberikan hasil positif sebesar $-32.1 \%$. Artinya, semakin tinggi dinamika kelompok maka semakin rendah peluang konteks kerentanannya. Hal tersebut mengindikasikan bahwa peranan kelembagaan sangat penting untuk kesejahteraan peternak. Kelembagaan juga berfungsi untuk meningkatkan nilai tawar peternak (Nasrul, 2012) dan akses peternak sapi perah terhadap berbagai jenis sumber daya (Mukson et al., 2017), sehingga menurut Anantanyu (2011) bahwa keberadaan kelembagaan dapat memperbaiki taraf hidup, harkat, dan martabat petani.

Aspek kelembagaan, sosial, ekonomi, dan lingkungan usaha ternak harus diperhatikan supaya mampu meningkatkan produktivitas dan pendapatan peternak (Mukson et al., 2012), oleh sebab itu Kalangi et al. (2014) menyatakan bahwa kelembagaan atau kelompok tani harus ditingkatkan sebab salah satu tujuannya yaitu memfasilitasi input produksi seperti penyediaan pakan dan kredit bagi peternak sapi perah, termasuk praproduksi dan pemasaran serta jasa penunjang (Prasetyo et al., 2012).

Kebijakan kelompok juga bertujuan untuk melindungi peternak sapi perah dari fluktuasi harga susu, sedangkan peranan pemerintah yaitu mampu mendorong investor baru untuk menghadapi ketidakstabilan harga susu (Indarsih et al., 2010), sehingga pentingnya pembinaan dan pendampingan kelompok sebagai bentuk pemberdayaan bisa dilakukan oleh Penyuluh Pertanian Lapang atau PPL (Ramdhani dkk, 2012).

Dinamika kelompok yang baik adalah yang mampu menjalankan fungsinya sebagai unit produksi (Rustandi dan Suhadji, 2017), sehingga menimbulkan adanya daya dukung tenaga kerja keluarga yang berdampak pada keputusan petani untuk meningkatkan skala usahanya (Roessali et al., 2011). Peningkatan skala usaha berdampak 
pada peningkatan produktivitas dan profitabilitas peternak sapi perah.

\section{SIMPULAN}

1. Dinamika kelompok peternak sapi perah dipengaruhi oleh sumber daya internal peternak sebesar 33\%. Sumber daya finansial memberikan pengaruh positif sebesar 0.306 , sumber daya teknologi memberikan pengaruh negatif sebesar -0.163 , dan sumber daya fisik memberikan pengaruh positif sebesar 0.219 .

2. Konteks kerentanan usaha ternak sapi perah dipengaruhi oleh sumber daya internal peternak dan dinamika kelompok sebesar $30.3 \%$. Sumber daya finansial memberikan pengaruh positif sebesar 0.002 , sumber daya teknologi memberikan pengaruh positif sebesar 0.463, dan sumber daya fisik memberikan pengaruh negatif sebesar -0.299.

\section{DAFTAR PUSTAKA}

Amam dan P. A. Harsita. 2019. Efek Domino Performa Kelembagaan, Aspek Risiko, dan Pengembangan Usaha terhadap SDM Peternak Sapi Perah. Sains Peternakan. 17 (1): 5-11.

Amam dan Soetriono. 2019. Evaluasi Performa Kelembagaan Peternak Sapi Perah Berdasarkan Aspek Risiko Bisnis dan Pengembangan Usaha. Jurnal Ilmu dan Teknologi Peternakan. 5 (3): 8-13.

Anantanyu, S. 2011. Kelembagaan Petani: Peran dan Strategi Pengembangan Kapasitasnya. Jurnal SEPA. 7 (2) : 102-109.

Asmara, A., Purnamadewi, Y. L., and Lubis, D. 2017. The Relationship Analysis between Service Performances of Milk Producer Cooperative with the Dairy Farm Performance of Members. Media Peternakan. 40 (2): 143-150.

Badan Pusat Statistik. 2017. Data Populasi dan Produksi Sapi Perah di Provinsi Jawa Timur.

Djalil, B. 2016. Model Penguatan Lembaga Petani sebagai Prime Mover Nilai Tambah Produk Pertanian. Jurnal Lentera. 14 (2) : 265-278.

Hermanto. 2018. Pengentasan Kemiskinan di Perdesaan: Pengembangan SDM, Penguatan Usaha, dan Inovasi Pertanian. Forum Penelitian Agro Ekonomi. 35 (2): 139-150.

Indarsih, B., M. H. Tamsil, dan M. P. Nugroho. 2010. A Study of Contract Broiler Production in Lombok, NTB: An
Opportunity of Intriducing Syari'ah Partnership. Media Peternakan. 33 (2): 124-130.

Kalangi, L. S., Syaukat, Y., Kuntjoro, S. U., and Priyanti, A. 2014. Technical Efficiency of Beef Cattle Breeding Business in East Java Province. Media Peternakan. 37 (2): 136142.

Mukson, M. Isbandi, Santosa, S. I., Sudjadmogo, Setiadi, A. 2012. Analysis of Various Factors in Order to Enhance Productivity and Income of Diary Cattle Farmers in Central Java, Indonesia. JITAA. 37 (3): 220-208.

Mukson, M., Setiawan, H., Handayani, M., and Setiadi, A. 2017. Analysis of The Local Resource-Based Dairy Cattle Development in Central Java. JITAA. 42 (1): 48-56.

Nasrul, W. 2012. Pengembangan Kelembagaan Pertanian untuk Meningkatkan Kapasitas Petani terhadap Pembangunan Pertanian. Jurnal Menara Ilmu. 3 (29) : 166-174.

Pakage, S., Hartono, B., Fanani, Z., Nugroho, B. A. 2015. Analysis of Technical, Allocative and Economic Efficiency of Broiler Production Using Closed House System in Malang District of East Java, Indonesia. LRRD. 27 (9): 1-8.

Perilla, M. V., Escala, J. M., and Setiadi, A. 2009. A Case Study of Luntian Multi-purpose Cooperative in Barangay Lalaig, Tiaong, Quezon, Philippines: A Vertical Integration Approach. JITAA. 34 (3): 216223.

Prasetyo, E., Sunarso, Santosa, P. B., Rianto. 2012. The Influence of Agribusiness Subsystem on Beef Cattle Fattening Farms Profit in Central Java. JITAA. 37 (2): 121126.

Ramdhani, H., Nulhaqim, S. A., dan Fedryansah, M. 2012. Peningkatan Kesejahteraan Petani dengan Penguatan Kelompok Tani. Jurnal Riset. 2 (3) 423-429.

Riszqina, Isbandi, Rianto, E., and Santoso, S. I. 2014. The Analysis of Factors Affecting The Performance in Benefits of Karapan (Racing) Cattle Business in Madura Island, East Java. JITAA. 39 (1): 65-72.

Roessali, W., Masyhuri, S. Nurtini, Darwanto, D. H. 2011. Factors Influencing Farmers Decision to Increase Beef Cattle Business Scale in Central Java Province. JITAA. 36 (1): 27-35.

Rustandi, Y. dan Suhadji, R. 2017. Keragaan dan Evaluasi Fungsi Kelembagaan Kelompok Tani di Kecamatan Papar Kabupaten 
Kediri Jawa Timur. Jurnal Agrica Ekstensia. 11 (2) : 55-60.Septiani, W., Marimin, Herdiyeni, Y., and Haditjaroko, L. 2017. Risk Based Milk Pricing Model at Diary Farmers Level. Media Peternakan. 40 (3): 218-227.

Sumekar, W., Isbandi, Atmomar-sono, U., and Susilowati, I. 2013. Business Performance of Duck Farmers in Brebes Regency, Central Java. JITAA. 38 (3): 171-175.

Suswandi dan Sutarno. 2017. Analisa Dinamika dan Kemandirian Kelembagaan Ekonomi Petani dengan Penerapan Pertanian Organik Bersertifikasi di Kabupaten Boyolali. Prosiding Seminar Nasional. 220-240.

Syukur, S. H., Fanani, Z., Nugroho, B. A., and Antara, M. 2014. Empowerment of Livestock Farmer through Graduate Program to Build a Village on Dynamics of Beef Cattle Farmer Groups Level of Gaduhan Model (A Case Study in the District of Toli-toli, Central Sulawesi. Journal of Natural Science Research. 4 (2): 107-112.

Tasripin, D. S. 2018. Kurangi Impor Susu, Pemerintah Harus Perhatikan Peternak Sapi Perah. Liputan 6. 25 April 2018, 09.45 WIB.

Tawaf, R., Paturochman, M., Herlina, R., Sulistiyati, M., and Fitriani, A. 2016. The Optimation of Farmers Familities Revenue The Integration of Pasundan Cattle and Paddy Farming in West Java. JITAA. 42 (4): 270-278.

Wiyono, G. 2011. Merancang Penelitian Bisnis dengan Alat Analisis SPSS 17.0 \& Smart PLS 2.0. Penerbit: Unit Penerbit dan Percetakan STIM YKPN Yogyakarta 